\title{
The Bcl-2 family of proteins and activation of the ICE-CED-3 family of proteases: A balancing act in apoptosis?
}

\author{
Sharad Kumar \\ The Hanson Centre for Cancer Research, P0 Box 14, Rundle Mall, Adelaide, \\ Australia 5000 tel: +61 (8) 82223738; fax: +61 (8) 82223139; \\ E-mail: skumar@immuno.imvs.sa.gov.au
}

In the nematode Caenorhabditis elegans, of the 1090 somatic cells produced during development, 131 cells die by programmed cell death (PCD). Horvitz and colleagues identified several genes that regulate various aspects of PCD in C. elegans (reviewed in Horvitz et al, 1994). Six of these genes are required for the phagocytosis of dying cells by neighbouring cells, one functions in DNA degradation, and three others are involved in the regulation of PCD in a few specific cells. The remaining three, ced-3, ced-4 and ced-9, regulate the process of apoptosis during the development of the nematode. The ced-9 gene was found to be essential for cell survival and gain of function mutations of this gene result in the survival of cells which would normally die during embryonic development. On the other hand, loss of ced-9 function results in the death of cells which would normally live. In contrast to ced-9, ced-3 and ced-4 are required for cell death to occur and consequently the loss of function of either of these gene results in the survival of cells which would normally die by PCD during the development of the worm.

Recent work by Shaham and Horvitz (1996) suggests that a competition between the death-inducing activities of ced-3 and ced-4 and the survival function of ced-9, determines the fate of specific cells. Evidence presented by these workers also suggests that in the genetic pathway of PCD in $C$. elegans, ced-4 is either in parallel or upstream of ced-3, while ced- 9 negatively regulates the activity of $c e d-4$.

Recent identification of proteins similar to CED-3 and CED-9 in mammalian cells suggested that the pathways of apoptosis have been essentially conserved during evolution. Several mammalian homologues of CED-3 (the ICE family of proteases) and CED-9 (the Bcl-2 family of proteins) have been discovered and the sheer number of these proteins indicates that the picture in mammals is much more complex than in the worm.

$\mathrm{Bcl}-2$ was initially identified as the gene at the breakpoint of $t(14: 18)(q 32 ; 21)$ a hallmark of human follicular lymphoma, and subsequently shown to inhibit apoptosis in a number of different systems (reviewed in Cory, 1995). Several proteins with structural similarity to $\mathrm{Bcl}-2$ have been found in mammalian cells. Of these, Mcl-1 and $\mathrm{Bcl}-\mathrm{x}_{\mathrm{L}}$ act like $\mathrm{Bcl}-2$ to promote cell survival, while others such as $\mathrm{Bax}, \mathrm{Bcl}-\mathrm{x}_{\mathrm{S}}$, Bak and Bad, antagonise the protective effects of $\mathrm{Bcl}-2$. Although the biochemical role of $\mathrm{Bcl}$-2-like proteins is poorly understood, members of the $\mathrm{Bcl}-2$ family share conserved domains that allow the formation of homo- and heterodimers (reviewed in Cory, 1995).

The members of the ICE family which currently number 11 , play a central effector role in apoptosis (reviewed in Kumar and Lavin, 1996). These proteases are produced as inactive precursors and require cleavage into two subunits prior to their activation. The activation of some of these proteases has been shown to occur in cells induced to undergo apoptosis (Chinnaiyan et al, 1996; Duan et al, 1996; Orth et al, 1996). Once activated, these proteases cleave several cellular proteins including poly(ADP-ribose) polymerase (PARP), the catalytic subunit of the DNAdependent protein kinase $\left(\mathrm{DNA}-\mathrm{PK}_{\mathrm{cs}}\right), \mathrm{U} 1$ small ribonucleoprotein (U1-70 kda), sterol regulatory element-binding proteins (SREBPs), heteronuclear ribonucleoproteins $\mathrm{C} 1$ and C2, and lamin A (reviewed in Kumar and Lavin, 1996).

Clearly, both Bcl-2 and ICE family members constitute the main body of the cell death machinery, however, there is currently little known about how the two groups of proteins regulate cell death. Initial observations suggested that $\mathrm{Bcl}-2$ can protect cell death induced by the overexpression of some ICE-like proteases (e.g. Miura et al, 1993; Kumar et al, 1994). However, these experiments did not clearly establish whether Bcl-2 is upstream or downstream of ICE-like proteases in the apoptotic pathway. Several papers published recently (Chinnaiyan et al, 1996; Erhardt and Cooper, 1996) and two in this issue of Cell Death and Differentiation (Perry et al, 1997; Estoppey et al, 1997) now show that overexpression of Bcl-2 can inhibit the activation of ICE-like proteases.

Perry and co-workers used Molt- 4 transfected with mouse bcl-2. As expected, these cells were considerably resistant to cell death induced by etoposide and did not show any cleavage of PARP after treatment with etoposide. Interestingly, the extracts from $\mathrm{Bcl}-2$ expressing cells also fail to cleave PARP in vitro while the extracts from the control Molt-4 cells treated with etoposide contained an active ICE-like protease which cleaved PARP. However, addition of $\mathrm{Bcl}-2$ protein to control extracts fails to inhibit the activated protease as assessed by lack of inhibition of PARP cleavage. These experiments clearly show that $\mathrm{Bcl}-2$ functions upstream of ICE-like proteases and prevents the activation of these proteases. The data also indicate that unlike $\mathrm{CrmA}$ and p35, Bcl-2 does not inhibit the activity of ICE-like proteases directly. Estoppey et al (1997) derived similar conclusions using staurosporine-induced apoptosis in HeLa cells as a model. HeLa cells overexpressing Bcl-2 were resistant to staurosporine-induced apoptosis and failed to show activation of the ICE-like protease CPP32. These investigators also show that staurosporine treatment of Bcl-2 expressing HeLa cells does not produce cleavage of PARP and U1-70 kda, two of the known targets of 
CPP32. In other related studies, Chinnaiyan et al (1996) have shown that $\mathrm{Bcl}-2$ and $\mathrm{Bcl}-\mathrm{x}_{\mathrm{L}}$ overexpression abrogates the activation of CPP32 and ICE-LAP3, and the cleavage of PARP in staurosporine treated Jurkat cells, while Erhardt and Cooper (1996) found that Bcl- $x_{L}$ inhibited the activation of CPP32 in U937 cells upon treatment with etoposide, inhibitors of PI-3-kinase or tumour necrosis factor.

How do these recent findings add to what we already know about the molecular regulation of cell death? Three general conclusions can be drawn: (i) these experiments firmly establish that the $\mathrm{Bcl}-2$ family of proteins act upstream of ICE-like proteases (ii) Bcl-2-like proteins do not directly inhibit ICE-like proteases but probably act upon an upstream activator and, (iii) a balance between Bcl-2 and ICE-like proteins determines the fate of the cell. In cases where the death preventive effect of $\mathrm{Bcl}-2$ is bypassed, such as in Fas and cytotoxic T-lymphocyte (CTL)-mediated apoptosis, the death stimuli can directly lead to the activation of ICE-like proteases. Activation of the Fas receptor leads to the recruitment of FADD, that in turn associates with FLICE/MACH, an ICE-like protease (Muzio et al, 1996; Boldin et al, 1996). The resulting activation of FLICE/MACH probably causes further activation of other downstream ICE-like proteases. The CTL-specific protease granzyme B cleaves several ICE family members into active subunits thereby avoiding the regulating effects of the Bcl-2 family of proteins. These two systems probably evolved to ensure that harmful cells, such as autoreactive lymphocytes and virus infected cells, are effectively removed without any interference from the protective effects of members of the Bcl-2 family of proteins in the target cells. As such, $\mathrm{Bcl}-2$ fails to protect apoptosis induced by Fas and CTL.

Having established the hierarchy between $\mathrm{Bcl}-2$ and ICE members, the next obvious questions is how Bcl-2 exerts its protective effect. To answer this will require the understanding of the biochemical role of $\mathrm{Bcl}-2$. One possible function of $\mathrm{Bcl}-2$ is to slow the cycling of cells by prolonging the $\mathrm{G}_{0} / \mathrm{G}_{1}$ phase (Boner, 1996), but how this is mediated is also unclear at present. Discovering components of 'the missing link' between Bcl-2 function and the ICE family will shed light on both the mechanism of Bcl-2 function and the activation of ICE-like proteases. It will also be very interesting to know whether a CED-4-like mammalian protein is part of this 'missing link'.

\section{References}

Boldin MP, Goncharov TM, Goltsev YV and Wallach D (1996) Involvement of MACH, a novel MORT1/FADD-interacting protease, in Fas/APO-1 and TNF receptorinduced cell death. Cell 85: 803-815

Boner C (1996) Diminished cell proliferation associated with the death-protective activity of Bcl-2. J. Biol. Chem. 271: 12695-12698

Chinnaiyan AM, Orth K, O'Rourke K, Duan H, Poirier GG and Dixit VM (1996) Molecular ordering of the cell death pathway: $\mathrm{Bcl}-2$ and $\mathrm{Bcl}-\mathrm{x}_{\mathrm{L}}$ function upstream of the CED-3-like apoptotic proteases. J. Biol. Chem. 271: 4573-4576.

Cory S (1995) Regulation of lymphocyte survival by the Bcl-2gene family. Annu. Rev. Immunol. 13: 513-543

Duan H, Chinnaiyan AM, Hudson PL, Wing JP, He W-W and Dixit VM (1996) ICELAP3, a novel mammalian homolog of the Caenorhabditis elegans cell death protein CED-3 is activated during Fas- and tumor necrosis factor-induced apoptosis. J. Biol. Chem. 271: 35013-35035

Erhardt P and Cooper GM (1996) Activation of the CPP32 apoptotic protease distinct signalling pathways with differential sensitivity to Bcl- $\mathrm{x}_{\mathrm{L}}$. J. Biol. Chem. 271: $17601-17604$

Estoppey S, Rodriguez I, Sadoul R and Martinou J-C (1997) BCL-2 prevents activation of CPP32 cysteine protease and cleavage of poly(ADP-ribose) polymerase and $\mathrm{U} 1-70 \mathrm{kD}$ proteins in staurosporine-mediated apoptosis. Cell Death Differ. 4: 34-38

Horvitz HR, Shaham S and Hengartner MP (1994) The genetics of programmed cell death in the nematode Caenhaorbditis elegans. Cold Spring Harbor Symp. Quant. Biol. 59: 377-385

Kumar S, Kinoshita M, Noda M, Copeland NG and Jenkins NA (1994) Induction of apoptosis by the mouse Nedd2 gene, which encodes a protein similar to the product of the Caenorhabditis elegans cell death gene ced-3and the mammalian IL-1 $\beta$-converting enzyme. Genes Develop. 8: 1613-1626

Kumar S and Lavin MF (1996) The ICE family of cysteine proteases as effector of cell death. Cell Death Differ. 3: 255-267

Miura M, Zhu H, Rotello R, Hartweig EA and Yuan J (1993) Induction of apoptosis in fibroblasts by IL-1 $\beta$-converting enzyme, a mammalian homolog of the $C$. elegans cell death gene ced-3. Cell 75: 653-660

Muzio M, Chinnaiyan A, Kischkel FC, O'Rourke K, Shevchenko A, Scaffidi C, Bretz JD, Zhange M, Ni J, Reiner G, Mann M, Krammer PH, Peter ME and Dixit VM (1996) FLICE, a novel FADD homologous ICE/CED-3-like protease, is recruited to the CD95 (Fas/Apo-1) death-inducing signalling complex. Cell 85: 817-827

Orth K, Chinnaiyan AM, Garg M, Froelich J and Dixit VM (1996) The CED-3/ICE-like protease Mch2 is activated during apoptosis and cleaves the death substrate lamin A. J. Biol. Chem. 271: 16443-16446

Perry DK, Smyth MJ, Wang H-G, Reed JC, Poirier GG, Obeid LM and Hannun YA (1997) Bcl-2 acts upstream of the PARP protease and prevents its activation. Cell Death Differ. 4: 29-33

Shaham S and Horvitz HR (1996) Developing Caenorhabditis elegans neurons may contain both cell-death protective and killer activities. Genes \& Dev. 10: 578 591 